\title{
The Effectiveness of RPT (Repetitive-Practice Technique) in Teaching Speaking Ability
}

\author{
Hanofi Harianto ${ }^{1}$, Hizbul Wathoni ${ }^{2}$, Ridwan ${ }^{3}$ \\ Selamet Riadi Jaelani ${ }^{4}$ \\ hanofikanjeng@gmail.com ${ }^{1}$ \\ Hizbulwathoni96@gmail.com ${ }^{2}$ \\ ridwanutan@gmail.com ${ }^{3}$ \\ selametriadijaelani@yahoo.com ${ }^{4}$ \\ Universiti Sultan Zainal Abidin, Terengganu, Malaysia ${ }^{1,2,3}$ \\ Universitas Hamzanwadi, Indonesia ${ }^{4}$
}

Received: November 2021

Accepted: November 2021

Online Published: Desember 2021

\begin{abstract}
This research aims to know the significant effect of RPT (Repetitive-Practice Technique) in teaching speaking at the tenth-grade students of SMA Al-Hasaniyah NW Jenggik in 2016-2017. This research was designed as preexperimental with pretest and posttest design. The study population was 27 and 27 as the sample in $X$ chosen by purposive random sampling it means the sample was taken purposively because the sample is representative. Speaking tests and analytical scoring rubric were used to collect the data. Then the data were analyzed using descriptive statistics and paired sample t-test to test the hypothesis, and it was performed by SPSS 22 for windows. The descriptive statistics analysis showed that RPT (Repetitive-Practice Technique) was effective in teaching speaking ability. It was proven by improving students' scores from 40.89 in Pre-Test and 58.96 in Post-Test. While the result of hypothesis testing using paired sample t-test at significance (2-tailed) value level was .000, it was lower than .05. RPT (Repetitive-Practice Technique) is significantly effective in teaching speaking ability. It was suggested that speaking in RPT (Repetitive-Practice Technique) is suitable for teaching speaking.
\end{abstract}

Keyword: Repetitive-Practice Technique, Speaking, Students' Ability

\section{Introduction}

Language is system of sound symbol used by humans to communicate (Akmajian et al., 2017). (Akmajian et al., 2017) said that "language as means of communication in which there are many languages which can be used in doing interaction with the other people". English is not only related to the efforts of guiding learners to be able to use English, but also to be skilled in speaking(Irwandi, 2020). One of the languages which is widely spoken is English. English in Indonesia is taught as a foreign language in all school levels (from elementary school up the university)

One of ways in communication is through speaking. Speaking is very important to be mastered by the learners (Safari \& Fitriati, 2016). In mastering speaking the learners must be active to speak not only in the class room but also outside the class room. According to (Leong \& Ahmadi, 2017), speaking is one way to communicate with ideas and though a message orally. It means that student must train to use English in communication orally. But in fact the teaching of speaking is not successful yet. It can be seen from the learners' performances in speaking and their responses towards speaking. Speaking is very complex for learners who study this 
skill (Gilakjani \& Sabouri, 2016). This skill has high difficulty which makes learners difficult to speak and convey something. So this skill must be mastered by the learners (Megawati \& Mandarani, 2016).

Based on the researcher observation, the problem faced by the student related to speaking ability is they hesitate to convey their ideas and they seldom use English for communicating in their daily activity. Actually their potencies are very good but when they want to speak English they are afraid to take mistake. English is still pretended as a monster for them so that's why they are shy and afraid to use English to communicate. They also pretend that English is just a lesson to be studied. Although they have studied English from elementary school, they still have difficulties in speaking English.

At SMA Al-Hasaniyah NW Jenggik the students are not good at English. They can pass exams easily but they cannot speak English in daily activity or confidence for the target topic orally. They are afraid of making mistakes in both grammar and pronunciation, so their friends will laugh at them that then make them ashamed, and of course it makes them look stupid in front of their friends and teacher. To help the students improve their speaking skill, it is necessary to find ways to help them overcome their problems. Moreover, the teachers need to know the factors that affect speaking skill. However, until now there is no research conducted at this school about these areas. In this problem that the researcher wants to give solution to the teacher to use RPT (repetitive-practice technique) in teaching speaking ability through practice the student will get more confidence, they are not clumsy that they also will get reflection when they want to speak (HIZBI, 2018). After using practice they then use repetition that automatically they repeat the words or expression every time and it will be habit for them which they are not be heavy to convey their idea when speaking.

However, through repetitive-practice in their daily activity will be perfect so that practice as one a drill to increase ability in speaking. In daily real practice is also needed by learners to know how far they can use the foreign language in their life interaction face to face. (Lee, 2016) interpreted widely to mean having students use language in genuine interactions.

It can be inferred that the learners will know the situation in the real world through practice with many people who they meet every day face to face as friend of interaction. So, the repetitions happen if they do it and it refers to daily practice.

\section{RESEARCH METHOD}

The population of the study was the tenth graders consist of one class (X). Meanwhile, the number of population was 27 students. The sample of the study was the students of class $\mathrm{X}$ of SMA NW Al-Hasaniyah NW Jenggik which consists of 27 students. The present researcher took the sample by purposive random sampling it means the sample taken purposively because the sample is representative.

In this research, the present researcher used instruments to take the data using audio recorder. The present researcher provided 5 questions which ask about the description of 
something and the students have to answer it orally by recording their selves during 5 minutes included to pre-test and post-test. To measure the students' speaking (Syafryadin \& Salniwati, 2019) mentions that speaking test aims out our assessment of the speaker's use of intelligibility, fluency, lexical accuracy, grammatical accuracy, word pronunciation accuracy, word stress, sentence stress, adjustment in connected speech, intonation, and rhythm. There are three steps which have been conducted in collecting data base on the research design. Those are pre-test, treatment, and post-test.

Before teaching process, the present researcher gave pre-test for the students to know the students basic knowledge in speaking. After giving the pre-test, the students were taught about descriptive text by applying repetitive-practice technique. The treatments took place within 4 meetings. Post-test was a test given to the students after conducting the treatment. An instrument was designed to measure the result of the treatment to find out whether there is significant difference between the pre-test and the post-test.

After collecting data the present researcher analysed it using SPSS 22 for windows. The researcher analysed the mean score and standard deviation using descriptive statistics. Then, then to find out the normality distribution, the present researcher used Shapiro-Wilk and to find out the homogeneity of variance One-Way Annova was used. And the last was paired-sample t-test for testing hypothesis.

\section{RESULTS AND DISCUSSION}

Based on the data that had been gotten in pre-test and post-test, the standard deviation of pre-test was 6.31 and post-test was 7.89. The lowest score of pre-test was 32 and the highest was56. On the other hand, the lowest score of the post-test was 40 and the highest score was 76. In addition, the mean score of pre-test was 40.89 meanwhile in post-test was 58.96. The mean score of post-test was higher than the mean scores of pre-test; it proves that RepetitivePractice Technique is effective in teaching speaking ability. According to the result of ShapiroWilk, it was found the value of Shapiro-Wilk in pre-test was 0.11 while in post-test was 0.31 . It proved that the data was normal because the values of the significance level of pre-test and post-test were more than the values of the significance $(p)=0.05$. Based on the calculation of One-Way ANOVA, the value of significance level $=.12$ and Levene's statistic was .11 . The value of significance level is more than 0.05 , it meant that the data was homogeneous. After performing Paired-Samples T-Test, the present researcher found that the mean difference between the mean score of pre-test and post-test was 18.16. In addition, the result of paired sample t-test which shown that there was a significant difference in the mean scores between post-test and pre-test, $\mathrm{t}=12.17$ at $\mathrm{p}=0.00$. This proves that null hypothesis was rejected and alternative hypothesis was accepted. It meant that Wheel Conversation Game was effective in teaching speaking at an EFL classroom.

After collecting and calculating the obtained data, the present researcher found that Repetitive-Practice Technique was effective in teaching speaking ability. It can be seen from 
the result of descriptive statistics where the mean score and standard deviation of post-test were higher than pre-test.

The result of the previous calculation indicated that there was improvement of students' speaking after treatment. In giving treatment the teacher allowed the students to find their weakness and their problem in English speaking. At the last of every meeting the teacher and the students solved the problems that had been gotten together. It improved the students' speaking. That why the mean score of post-test was higher than pre-test. In conclusion, Repetitive-Practice Technique was successful in teaching speaking ability

(Gibson et al., 2019) stated that "Language is human's unique communication tool because just human has language as a tool of communication and even not the only tool the human has". It means that human also can communicate with different way out of language.

Language is used in spoken or written communication. Speaking or oral communication involves the negotiation of meaning between two or more person; it is always related to the context in which it occurs (Fauzan, 2016). Speaking negotiation intended meaning and adjusting one's speech to procedure the desired effect on the listener as cited (Myers-Scotton, 2020). Linguist said that language is speaking. Speaking is one of language skills that develop in children's life begin from listening, in the same time where speaking is learnt (Cole \& Flexer, 2019).

Related to research finding, it deals with the research was conducted by (HIZBI, 2018) by the title The Effectiveness Of Using Describe and Draw Technique to Improve Students Speaking Ability in Descriptive Text. This research aimed at examining the effectiveness of Describe and Draw Technique in teaching speaking ability. Design this research was a preexperimental research with pre-test and post-test design. It was conducted at the eleventh graders of MA NW Suralaga in the school year 2017-2018. The sample consist 28 students. The data was collected using oral test. The data were analysed by using statistics 22 for windows. The result of descriptive statistics indicated that Describe and Draw Technique was effective with the mean score of post-test 73.64 was higher than mean score of pre-test 48.50 . For hypothesis testing using paired-sample t-test at significance (2-tailed) value level of analysing data was .00 , it was lower than .05 , it means the alternative hypothesis of this study was accepted. Therefore, Describe and Draw Technique is effective in teaching speaking skills for the eleventh graders of MA NW Suralaga in the school year 2017-2018. Considering process and results of this research, the present researcher suggested that the English teacher use Describe and Draw Technique in teaching speaking especially in descriptive text. Key Words: Describe and Draw Technique, speaking ability.

Therefore, Repetitive-Practice Technique that as an additional activity in teaching speaking is repetitive-practice. In the result of this research is that Repetitive-Practice Technique is significantly effective in teaching speaking ability.

\section{CONCLUSION}


Referring to the result of the research, the researcher got some conclusions as: The mean score of pre-test was lower than post-test. It means that repetitive-practice technique is effective in teaching speaking and Repetitive-Practice Technique was significantly effective in teaching speaking ability. It can be seen from the result of Paired-Samples t-test where the sig. 2 tailed was lower than 0.05. and there are some suggestion from the present researcher such as: It is suggested that teachers use repetitive-practice technique as an additional activity in teaching speaking because it helps students to practice their knowledge especially their speaking and can become more active in classroom; Before assigning the repetitive-practice to the students, the teacher should make sure that the students have fully understood and have the information they need. It means that before applying the repetitive-practice technique, it is better if the teacher makes sure all the materials that are needed are ready; the teachers have to be careful in controlling the class because this technique can cause the teachers lost control. The class will be noisy because of the students' voice when they are conversing.

\section{AUTHOR'S STATEMENT}

The author declares that this article has never been published in any journal.

\section{REFERENCES}

Akmajian, A., Farmer, A. K., Bickmore, L., Demers, R. A., \& Harnish, R. M. (2017). Linguistics: An introduction to language and communication. MIT press.

Cole, E. B., \& Flexer, C. (2019). Children with hearing loss: Developing listening and talking, birth to six. Plural Publishing.

Fauzan, U. (2016). Enhancing speaking ability of EFL students through debate and peer assessment.

Gibson, E., Futrell, R., Piantadosi, S. P., Dautriche, I., Mahowald, K., Bergen, L., \& Levy, R. (2019). How efficiency shapes human language. Trends in Cognitive Sciences, 23(5), 389407.

Gilakjani, A. P., \& Sabouri, N. B. (2016). Learners' Listening Comprehension Difficulties in English Language Learning: A Literature Review. English Language Teaching, 9(6), 123133.

HIZBI, N. U. R. L. H. (2018). The Effectiveness Of Using Describe And Draw Technique To Improve Students Speaking Ability In Descriptive Text. Universitas Hamzanwadi.

Irwandi, I. (2020). Implementing Eclectic Method for ELT through Distance Learning during the Covid-19 Pandemic. Educatio, 15(2), 91-103.

Lee, L. (2016). Autonomous learning through task-based instruction in fully online language courses. Language Learning \& Technology, 20(2), 81-97.

Leong, L. M., \& Ahmadi, S. M. (2017). An Analysis Of Factors Influencing Learners'english Speaking Skill.

Megawati, F., \& Mandarani, V. (2016). Speaking Problems in English Communication. 
Myers-Scotton, C. (2020). Code-switching as indexical of social negotiations. In The bilingualism reader (pp. 97-122). Routledge.

Safari, M. U. K., \& Fitriati, S. W. (2016). Learning strategies used by learners with different speaking performance for developing speaking ability. English Education Journal, 6(2), 87-100.

Syafryadin, H., \& Salniwati, A. (2019). Digital storytelling implementation for enhancing students' speaking ability in various text genres. International Journal of Recent Technology and Engineering (IJRTE), 8(4), 3147-3151. 